\title{
COVID-19 Outcomes and Genomic Characterization of SARS-CoV-2 Isolated From Veterans in New England States: Retrospective Analysis
}

Megan Lee ${ }^{1^{*}}$, BS; Ya Haddy Sallah ${ }^{1^{*}}$, MPH, MD; Mary Petrone ${ }^{2 *}, \mathrm{BS} ;$ Matthew Ringer ${ }^{1}$, MD; Danielle Cosentino ${ }^{3}$, BS; Chantal B F Vogels ${ }^{2}$, PhD; Joseph R Fauver ${ }^{2}, \mathrm{PhD}$; Tara D Alpert ${ }^{2}$, PhD; Nathan D Grubaugh ${ }^{2}$, PhD; Shaili Gupta $^{1,3}$, MBBS

\footnotetext{
${ }^{1}$ Yale School of Medicine, West Haven, CT, United States

${ }^{2}$ Yale School of Public Health, New Haven, CT, United States

${ }^{3}$ VA Connecticut Healthcare System, West Haven, CT, United States

*these authors contributed equally
}

\section{Corresponding Author:}

Shaili Gupta, MBBS

VA Connecticut Healthcare System

950 Campbell Ave

Bldg 1, Floor 5, Dept of Medicine, Mailstop 111a

West Haven, CT, 06516

United States

Phone: 12039325711 ext 4412

Fax: 12039374784

Email: shaili.gupta@yale.edu

\section{Related Articles:}

Preprint (medRxiv): https://www.medrxiv.org/content/10.1101/2021.04.27.21256222v3

Preprint (JMIR Preprints): https://preprints.jmir.org/preprint/31503

Peer-Review Report by Mathew Mbwogge (Reviewer W): https://med.jmirx.org/2021/4/e35516/

Peer-Review Report by Lei Guo (Reviewer AV): https://med.jmirx.org/2021/4/e35517/

Authors' Response to Peer-Review Reports: https://med.jmirx.org/2021/4/e35515/

\section{Abstract}

Background: Clinical and virologic characteristics of COVID-19 infections in veterans in New England have not been described. The average US veteran is a male older than the general US population. SARS-CoV-2 infection is known to cause poorer outcomes among men and older adults, making the veteran population an especially vulnerable group for COVID-19.

Objective: This study aims to evaluate clinical and virologic factors impacting COVID-19 outcomes.

Methods: This retrospective chart review included 476 veterans in six New England states with confirmed SARS-CoV-2 infection between April and September 2020. Whole genome sequencing was performed on SARS-CoV-2 RNA isolated from these veterans, and the correlation of genomic data to clinical outcomes was evaluated. Clinical and demographic variables were collected by manual chart review and were correlated to the end points of peak disease severity (based on oxygenation requirements), hospitalization, and mortality using multivariate regression analyses.

Results: Of 476 veterans, 274 had complete and accessible charts. Of the 274 veterans, $92.7 \%(n=254)$ were men and $83.2 \%$ $(\mathrm{n}=228)$ were White, and the mean age was 63 years. In the multivariate regression, significant predictors of hospitalization $(\mathrm{C}$ statistic 0.75 ) were age (odds ratio [OR] 1.05, 95\% CI 1.03-1.08) and non-White race (OR 2.39, 95\% CI 1.13-5.01). Peak severity (C statistic 0.70 ) also varied by age (OR 1.07, 95\% CI 1.03-1.11) and O2 requirement on admission (OR 45.7, 95\% CI 18.79-111). Mortality (C statistic 0.87) was predicted by age (OR 1.06, 95\% CI 1.01-1.11), dementia (OR 3.44, 95\% CI 1.07-11.1), and O2 requirement on admission (OR 6.74, 95\% CI 1.74-26.1). Most (291/299, 97.3\%) of our samples were dominated by the spike protein D614G substitution and were from SARS-CoV-2 B.1 lineage or one of 37 different B.1 sublineages, with none representing more than $8.7 \%(26 / 299)$ of the cases. 
Conclusions: In a cohort of veterans from the six New England states with a mean age of 63 years and a high comorbidity burden, age was the largest predictor of hospitalization, peak disease severity, and mortality. Non-White veterans were more likely to be hospitalized, and patients who required oxygen on admission were more likely to have severe disease and higher rates of mortality. Multiple SARS-CoV-2 lineages were distributed in patients in New England early in the COVID-19 era, mostly related to viruses from New York State with D614G mutation.

(JMIRx Med 2021;2(4):e31503) doi: 10.2196/31503

\section{KEYWORDS}

infectious disease; COVID-19; epidemiology; veteran; outcome; sequencing; genetics; virus; United States; impact; testing; severity; mortality; cohort

\section{Introduction}

\section{Background}

Disease severity and outcomes of COVID-19 caused by SARS-CoV-2 vary among individuals who become infected, with several factors that have been suggested as predictors of mortality, including Charlson comorbidity index score, age, and BMI [1-6]. Other comorbidities such as cardiovascular disease, diabetes, and dementia are prevalent in patients who are hospitalized and can predict worse outcomes and complications following infection, but the current literature shows variable impacts of comorbidities in different populations [7-15].

Virologic characteristics have been suggested to impact the severity of disease, and concern has been raised about several variants being more transmissible or more lethal [16-18]. A dynamic nomenclature system (Pangolin) was developed to classify SARS-CoV-2 and identify lineages and mutations that could impact infectivity and virulence [19]. In the early era of COVID-19, there was significant concern about the D614G variant being more infectious, and SARS-CoV-2 with this mutation had been found to cause infections in New York State $[17,20]$. Evaluation of prevalence of this virus in the nearby states therefore became of substantial interest. Viral epidemiology and regional evaluation of viral variants, with their clinical correlations, are important to provide a full understanding of the disease.

\section{Study Rationale}

Given the high variability and conflicting data in predicting who will have poor outcomes, assessment of specific populations is necessary to give providers the best clinical picture on their patients. The US veteran population is predominantly male $(89 \%)$ with an average age of 58 years, compared to the general US population that has a median age of 38.5 years and a gender distribution of 98.2 males to every 100 females [21,22]. Both older age and male sex have been found to be independent predictors of greater disease severity and mortality in COVID-19 infections [8,13,23-26]. Evaluation of clinical outcomes among US veterans, a population predisposed to poorer outcomes because of these demographic variables, therefore, is important. Clinical outcomes of veterans with COVID-19 in New England and SARS-CoV-2 genomics have not been described. Outcome assessment based on unique demographic and clinical variables in people infected with novel viruses cannot be overemphasized. Given the high mutability of SARS-CoV-2, changing epidemiological trends over time, and known impact of virological factors on clinical outcomes, this study becomes even more important as it will provide an insight into this unique regional population with COVID-19 at a relevant time period in the evolution of the virus.

\section{Study Aims}

We aimed to describe patient characteristics, comorbidities, and disease factors that impact patient outcomes and present data on the genomic composition of the SARS-CoV-2 infecting these patients.

\section{Methods}

\section{Specific Objectives}

This study aims to determine the clinical and virologic factors impacting outcomes in veterans with COVID-19.

\section{Study Design With Justification}

We conducted a retrospective chart review to gather demographic and clinical variables as well as clinical outcomes. The Veterans Affairs (VA) health care system has electronic medical records that can be accessed to extract this information. We have conducted such chart reviews before to help inform management decisions based on predictors of outcomes [27].

\section{Study Setting}

In 2020, the VA health care system in West Haven, Connecticut had been entrusted with testing for SARS-CoV-2 for all six VA health care centers in New England states (Connecticut, Massachusetts, Maine, New Hampshire, Rhode Island, Vermont). The virus, isolated from samples testing positive, was then sent for whole genome sequencing (WGS) under an agreement funded by the Centers for Disease Control and Prevention (CDC).

\section{Participants (Sample Size and Inclusion Criteria)}

This study included all veterans who tested positive for COVID-19 from April 8, 2020, to September 16, 2020, at any of the six New England VA hospitals. Inclusion criteria included patients with accessible chart records and a diagnosis of COVID-19 based on one of three polymerase chain reaction-based tests: Xpert Xpress SARS-CoV-2 (Cepheid), Simplexa COVID-19 Direct Kit (DiaSorin), and Roche cobas 6800 system.

\section{Data Collection}

We manually reviewed charts and recorded demographics (age, gender, race, BMI, long-term care [LTC] facility status, and 
state of residence when diagnosed with COVID-19). Comorbidities recorded were immunosuppression, dementia, diabetes mellitus, chronic kidney disease stage 3, chronic liver disease, coronary artery disease (CAD), heart failure, atrial fibrillation, chronic obstructive pulmonary disease, asthma, and active tobacco use. All data collection was retrospective after a diagnosis of COVID-19 had been confirmed. If chart review occurred while a veteran was hospitalized, the chart was again reviewed retrospectively after discharge from the hospital.

\section{Sample Collection and Handling}

Handling of nasopharyngeal specimens or isolated virus was carried out by the VA Connecticut Healthcare System (VACHS) clinical laboratory as part of clinical care, following standardized Clinical Laboratory Improvement Amendments guidelines [28]. Our viral repository was populated by the positive test results of all New England veterans. The VACHS laboratory handled specimens, isolated the SARS-CoV-2 RNA, and shipped it for WGS to a non-VA laboratory. We obtained the details of the platform used to diagnose, the cycle threshold $(\mathrm{Ct})$, and the date of test from the laboratory. Sequencing of viral genomes was conducted at the non-VA laboratory by our coauthors as follows.

\section{Genomic Sequencing and Phylogenetic Analysis}

Whole virus genomes were sequenced ( $\geq 20 \mathrm{x}$ coverage depth across $\geq 70 \%$ of the genome) using the Illumina $(n=238)$ and Nanopore $(n=61)$ platforms. WGS was conducted on SARS-CoV-2 isolates with a $\mathrm{Ct}$ value $<36$ and provided near-complete or complete genome results where the $\mathrm{Ct}$ value was <30. Using BWA-MEM version 0.7.15 (GNU Project), we aligned reads to the Wuhan-Hu-1 reference genomes (GenBank MN908937.3). With iVar v1.2.1 (Andersen Lab), we trimmed sequencing adaptors and primer sequences, and called bases by simple majority ( $>50 \%$ frequency) at each site to generate consensus genomes. An ambiguous $\mathrm{N}$ was used when $<10$ reads were present at a site. We aligned consensus genomes with MAFFT (GNU Project) [29] and masked problematic sites [30]. We built a phylogenetic tree with IQTree (IQ-Tree) [31] using an HKY substitution model and 1000 bootstraps, visualized it with Python module baltic v0.1.5 (Python Software Foundation), and assigned lineages with Pangolin [19].

\section{Outcome Measures}

Our categorical outcomes, also derived from manual chart review, were hospitalization status, mortality, and oxygen $\left(\mathrm{O}_{2}\right)$ requirement within 24 hours of admission from manual chart review. We divided patients based on their peak disease severity (ordinal) into five categories depending on oxygenation requirements: (1) no $\mathrm{O}_{2}$ requirement, (2) 1 to 3 liters by nasal cannula (NC), (3) 4 to 6 liters by $\mathrm{NC}$, (4) $>6$ liters $\mathrm{O}_{2}$ or noninvasive positive pressure ventilation, and (5) mechanical ventilation. Mortality was defined as death within 60 days from the date of diagnosis.

\section{Data Analysis}

We used STATA v16 (StataCorp) for logistic regressions to predict our hospitalization and mortality, and ordinal logistic regression to predict peak disease severity. We first conducted a univariate analysis, then used significant variables from the univariate analysis $(P<.05)$ to use in a multivariate model for each of our outcomes to assess the impact of several variables at once, which has been frequently used in COVID-19 literature [9,10,32-34]. Assumptions for logistic regressions (binary outcome, linearity, no outliers, and multicollinearity) were tested and met, with maximum variance inflation factors of 2 . Genomic characteristics were reported descriptively.

\section{Ethical Considerations}

The VACHS Institutional Review Board approved the creation and maintenance of a data repository of all veterans in New England diagnosed with COVID-19 and a viral repository of the SARS-CoV-2 RNA received from all six New England facilities. This study was conducted in accordance with the Declaration of Helsinki, keeping all private health information secure in approved secure folders behind a VA firewall. The RECORD (Reporting of Studies Conducted Using Observational Routinely-Collected Data) statement guidelines were used to maintain transparency in the reporting of this study [35].

\section{Results}

\section{Participant Characteristics}

Of 476 veterans in six New England states with confirmed SARS-CoV-2 during the study period, 274 had complete and accessible charts. Of 274 veterans, 93\% $(n=254)$ were men, $83 \%(\mathrm{n}=228)$ were White, the mean age was 63 (SD 17.6) years, and over one-third resided were in LTC $(n=92$; Table 1$)$. The most common comorbidities were CAD $(n=74)$, diabetes $(n=68)$, and tobacco use $(n=62)$. 
Table 1. Patient characteristics $(\mathrm{n}=274)$.

\begin{tabular}{|c|c|}
\hline Demographics & Participants \\
\hline Age (years), mean (SD) & $62.9(17.6)$ \\
\hline \multicolumn{2}{|l|}{ Gender, n (\%) } \\
\hline Male & $254(93)$ \\
\hline Female & $20(7)$ \\
\hline \multicolumn{2}{|l|}{ Race, $n(\%)$} \\
\hline White & $228(83)$ \\
\hline Non-White & $46(17)$ \\
\hline $\mathrm{BMI}>30, \mathrm{n}(\%)$ & $110(40)$ \\
\hline From LTC ${ }^{\mathrm{a}}, \mathrm{n}(\%)$ & $92(34)$ \\
\hline \multicolumn{2}{|l|}{ State, $\mathrm{n}(\%)$} \\
\hline Connecticut & $89(32)$ \\
\hline Massachusetts & $150(55)$ \\
\hline Maine & $4(1)$ \\
\hline New Hampshire & $9(3)$ \\
\hline Rhode Island & $20(7)$ \\
\hline Vermont & $2(1)$ \\
\hline \multicolumn{2}{|l|}{ Comorbities, n (\%) } \\
\hline Immunosuppressed & $10(4)$ \\
\hline Dementia & $42(15)$ \\
\hline Diabetes & $68(25)$ \\
\hline $\mathrm{CKD}^{\mathrm{b}} 3$ & $18(7)$ \\
\hline Chronic liver disease & $32(12)$ \\
\hline Chronic heart disease & $107(39)$ \\
\hline $\mathrm{CAD}^{\mathrm{c}}$ & $74(27)$ \\
\hline Heart failure & $29(11)$ \\
\hline Atrial fibrillation & $40(15)$ \\
\hline Chronic lung disease & $97(35)$ \\
\hline $\operatorname{COPD}^{\mathrm{d}}$ & $44(16)$ \\
\hline Asthma & $19(7)$ \\
\hline $\mathrm{OSA}^{\mathrm{e}}$ & $55(20)$ \\
\hline Tobacco use & $62(23)$ \\
\hline
\end{tabular}

${ }^{\mathrm{a}}$ LTC: long-term care.

${ }^{\mathrm{b}} \mathrm{CKD}$ : chronic kidney disease.

${ }^{\mathrm{c}} \mathrm{CAD}$ : coronary artery disease.

${ }^{\mathrm{d}}$ COPD: chronic obstructive pulmonary disease.

${ }^{\mathrm{e} O S A}$ : obstructive sleep apnea.

\section{Rates and Predictors of Hospitalization, Peak Severity, and Mortality}

Notably, $12 \%(\mathrm{n}=33)$ of patients required $\mathrm{O}_{2}$ above their baseline home $\mathrm{O}_{2}$ requirement within 24 hours of admission, and $21 \%$ $(n=58)$ of all patients required $\mathrm{O}_{2}$ support at some point during hospitalization. In terms of peak severity, $79 \%(\mathrm{n}=216)$ required only room air, $11 \%(n=30)$ required 1 to 3 liters $\mathrm{O}_{2}, 4.0 \%(\mathrm{n}=11)$ required 4 to 6 liters $\mathrm{O}_{2}, 3.6 \%(\mathrm{n}=10)$ required $>6$ liters $\mathrm{O}_{2}$ or noninvasive positive-pressure ventilation, and $2.2 \%(\mathrm{n}=6)$ were intubated. The hospitalization rate was $29 \%(\mathrm{n}=79$; Figure 1), and the overall mortality rate was $11 \%(n=30$; Figure 2$)$. 
Figure 1. Percent of patients hospitalized based on patient demographics and comorbidities. CAD: coronary artery disease; CKD: chronic kidney disease; COPD: chronic obstructive pulmonary disease; LTC: long-term care; OSA: obstructive sleep apnea.

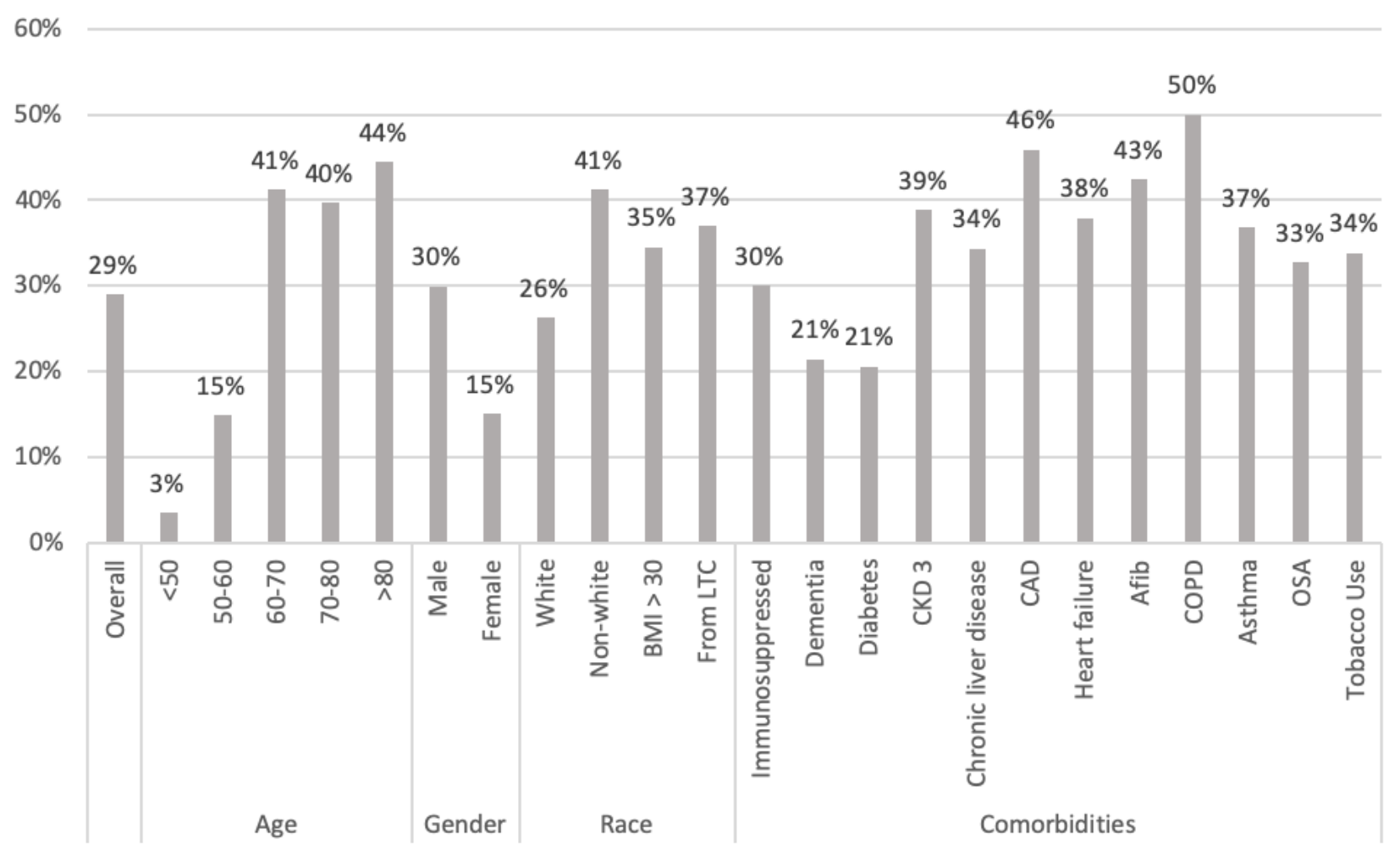

Figure 2. Percent of patients who died based on patient demographics and comorbidities. CAD: coronary artery disease; CKD: chronic kidney disease; COPD: chronic obstructive pulmonary disease; LTC: long-term care; OSA: obstructive sleep apnea.

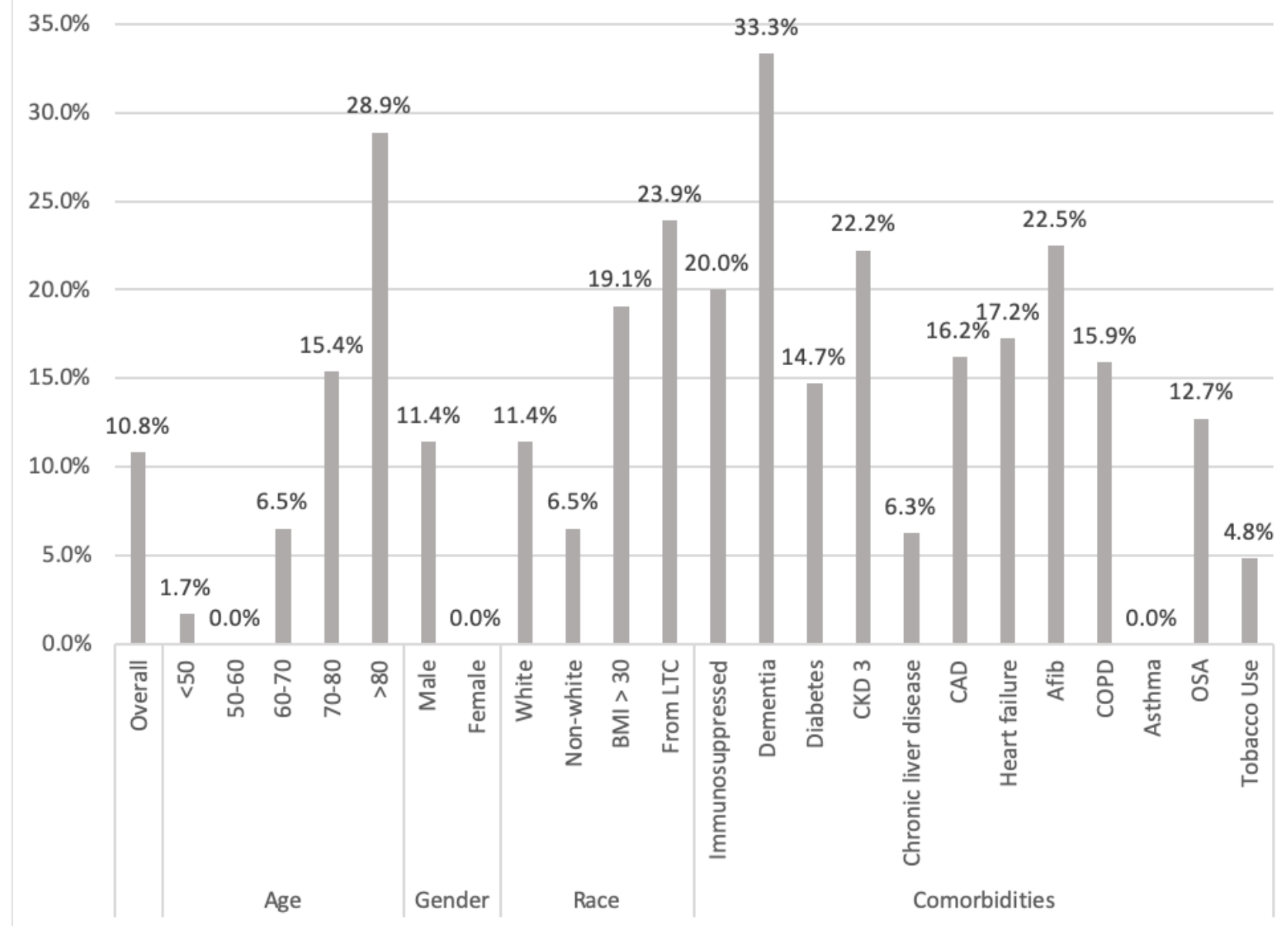


Univariate regression analysis results are reported in Table 2. In the multivariate regression (Table 2), significant predictors of hospitalization (C statistic 0.75 ) were age (odds ratio [OR] $1.05,95 \%$ CI 1.03-1.08) and non-White race (OR 2.39, 95\% CI 1.13-5.01; Table 2). Peak severity (C statistic 0.70) also varied by age (OR 1.07, 95\% CI 1.03-1.11) and $\mathrm{O}_{2}$ requirement on admission (OR 45.7, 95\% CI 18.79-111). Mortality (C statistic 0.87) was predicted by age (OR 1.06, 95\% CI 1.01-1.11), dementia (OR 3.44, 95\% CI 1.07-11.1), and $\mathrm{O}_{2}$ requirement on admission (OR 6.74, 95\% CI 1.74-26.1). In other words, for every year increase in age, the odds of hospitalization increased by $5 \%$, peak severity increased by $7 \%$, and mortality increased by $6 \%$.

Table 2. Univariate and multivariate regression analysis of factors that predict hospitalization, peak severity, and death.

\begin{tabular}{|c|c|c|c|c|c|c|}
\hline & \multicolumn{2}{|l|}{ Hospitalization } & \multicolumn{2}{|l|}{ Peak severity } & \multicolumn{2}{|l|}{ Death } \\
\hline & Unadjusted $\mathrm{OR}^{\mathrm{a}}(95 \% \mathrm{CI})$ & $P$ value & Unadjusted OR (95\% CI) & $P$ value & Unadjusted OR (95\% CI) & $P$ value \\
\hline \multicolumn{7}{|l|}{ Univariate regression } \\
\hline Age & $1.06(1.03-1.08)$ & $<.001^{b}$ & $1.06(1.04-1.09)$ & $<.001$ & $1.1(1.06-1.14)$ & $<.001$ \\
\hline Female gender & $0.41(0.12-1.45)$ & .17 & $0.42(0.95-1.9)$ & .26 & $\mathrm{~N} / \mathrm{A}^{\mathrm{c}}$ & $\mathrm{N} / \mathrm{A}$ \\
\hline Non-White race & $1.97(1.02-3.8)$ & .04 & $1.3(0.6-2.6)$ & .55 & $0.54(0.16-1.9)$ & .33 \\
\hline From long-term facility & $1.78(1.04-3.07)$ & .04 & $2.8(1.5-5.1)$ & .001 & $7.9(3.2-19.2)$ & $<.001$ \\
\hline BMI $<30$ & $1.52(0.9-2.7)$ & .14 & $1.1(0.6-2)$ & .77 & $5.8(2.1-15.9)$ & .001 \\
\hline Dementia & $0.63(0.29-1.4)$ & .25 & $1.6(0.7-3.3)$ & .26 & $7.2(3.2-16.6)$ & $<.001$ \\
\hline $\mathrm{COPD}^{\mathrm{d}}$ & $3.04(1.6-5.9)$ & .001 & $1.5(0.74-3.2)$ & .25 & $1.8(0.7-4.5)$ & .22 \\
\hline Heart failure & $1.6(0.7-3.5)$ & .25 & $1.8(0.8-4.0)$ & .18 & $1.9(0.67-5.5)$ & .23 \\
\hline $\mathrm{CAD}^{\mathrm{e}}$ & $2.93(1.66-5.2)$ & $<.001$ & $2.1(1.2-3.9)$ & .02 & $2.1(0.9-4.6)$ & .07 \\
\hline Atrial fibrillation & $2.05(1.03-4.1)$ & .04 & $3(1.4-5.9)$ & .002 & $3.1(1.3-7.4)$ & .01 \\
\hline Hospitalization & N/A & N/A & N/A & N/A & $2.58(1.18-5.65)$ & .02 \\
\hline $\mathrm{O}_{2}$ on admission & N/A & N/A & $46.2(19.9-107.3)$ & $<.001$ & $4.34(1.77-10.6)$ & .001 \\
\hline \multicolumn{7}{|l|}{ Multivariate regression } \\
\hline Age & $1.05(1.03-1.08)$ & $<.001$ & $1.07(1.03-1.11)$ & $<.001$ & $1.06(1.01-1.11)$ & .02 \\
\hline Non-White race & $2.39(1.13-5.01)$ & .02 & N/A & N/A & N/A & N/A \\
\hline From long-term facility & $0.70(0.36-1.38)$ & .31 & $1.18(0.55-2.55)$ & .67 & $2.0(0.58-6.88)$ & .27 \\
\hline BMI $<30$ & N/A & N/A & N/A & N/A & $2.95(0.81-10.75)$ & .10 \\
\hline Dementia & N/A & N/A & N/A & N/A & $3.44(1.07-11.1)$ & .04 \\
\hline COPD & $1.73(0.84-3.35)$ & .14 & N/A & N/A & N/A & N/A \\
\hline CAD & $1.44(0.75-2.81)$ & .27 & $0.71(0.32-1.55)$ & .39 & $0.57(0.209-1.57)$ & .28 \\
\hline Atrial fibrillation & $0.984(0.45-2.16)$ & .97 & $1.11(0.46-2.64)$ & .82 & $1.25(0.42-3.69)$ & .69 \\
\hline Hospitalization & N/A & N/A & N/A & N/A & $1.36(0.40-4.65)$ & .63 \\
\hline $\mathrm{O}_{2}$ on admission & N/A & N/A & $45.7(18.79-111)$ & $<.001$ & $6.74(1.74-26.1)$ & .006 \\
\hline
\end{tabular}

${ }^{\mathrm{a} O R}$ : odds ratio.

${ }^{\mathrm{b}}$ Italics indicate that $P<.05$ (exact values reported).

${ }^{\mathrm{c}} \mathrm{N} / \mathrm{A}$ : not applicable.

${ }^{\mathrm{d}}$ COPD: chronic obstructive pulmonary disease.

${ }^{\mathrm{e}} \mathrm{CAD}$ : coronary artery disease.

\section{Genomic Characteristics}

For the genomic characteristics, among the 476 patients, 299 patients' genomes had adequate coverage for analysis. We found the majority of our specimens $(154 / 299,51.5 \%)$ were from SARS-CoV-2 lineage B.1 or a sublineage of B.1 (eg, B.1.302, B.1.303, B.1.356; 137/299, 46\%), all of which are defined by
D614G substitution (Figure 3, Multimedia Appendix 1). Only $2.4 \%$ (7/299) were from the lineage A that lack the D614G mutation. There were 41 different SARS-CoV-2 lineages detected in our cohort, and we did not have the power to test for clinical correlates. Our sequencing data does inform us that the outcomes presented in this VA cohort are dominated by the impacts of the B lineage D614G mutation. 
Figure 3. Maximum likelihood tree of genomes.

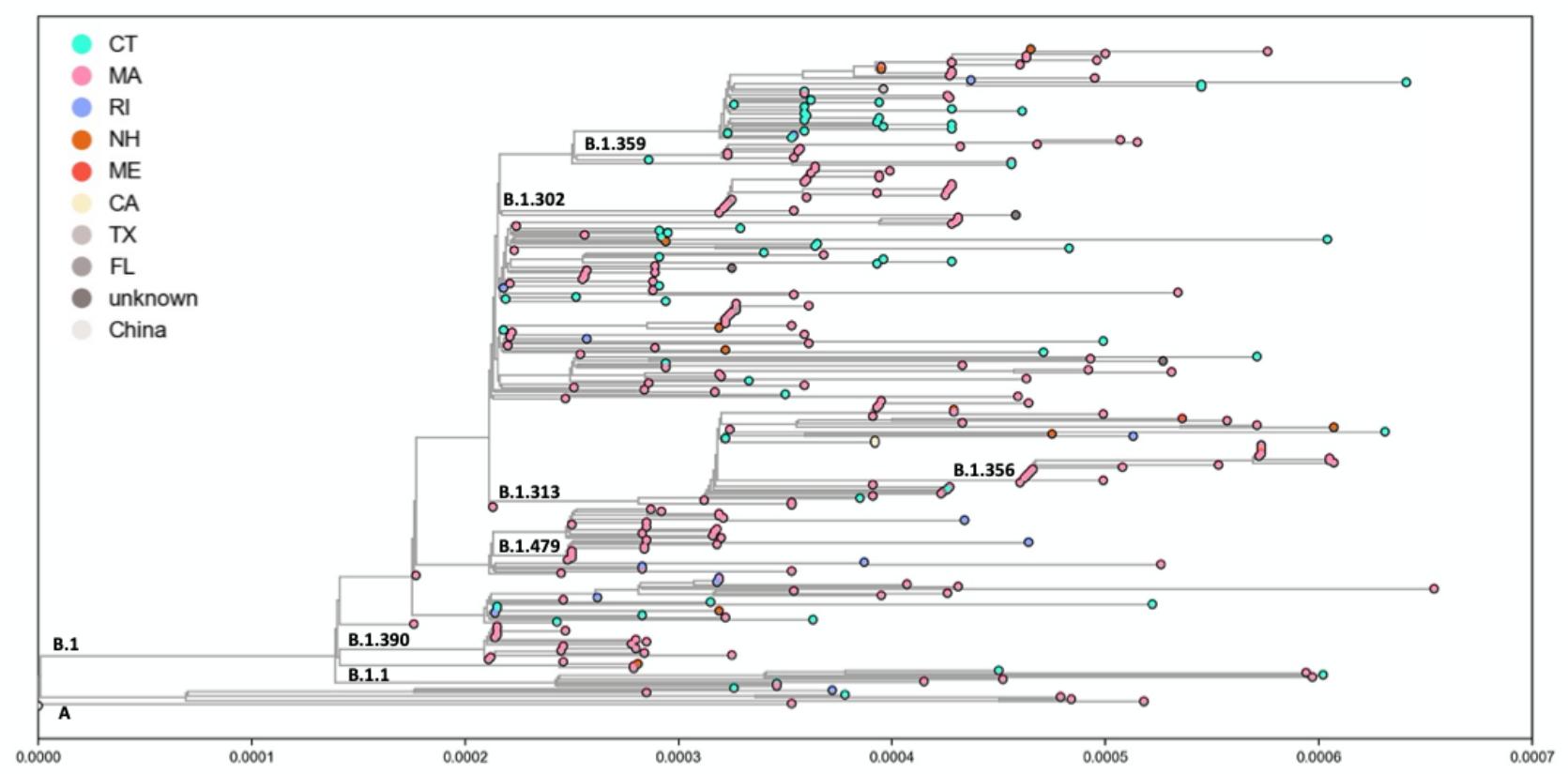

\section{Discussion}

\section{Principal Findings}

Our study found that in a cohort of veterans with an average age of 63 years and a high comorbidity burden, age was significantly associated with risk of hospitalization, peak disease severity, and mortality. $\mathrm{O}_{2}$ requirement upon admission correlated with peak disease severity and mortality, while dementia was an additional factor associated with higher mortality. The CDC provides a list of chronic medical conditions (May 2021) that predispose individuals to severe illness from SARS-CoV-2 infection [6]. Based on this list, $>75 \%$ of US adults fall under a high-risk category [36], therefore making it important to have select populations evaluated for uniquely applicable risk factors. Veterans are a unique cohort because of advanced age on average [22] and more comorbidities. Understanding clinical factors that impact outcomes in veterans will help health care providers risk-stratify patients with similar demographic profiles, and future research should explore the impact of new treatments and vaccination on outcomes. The predominance of B lineage D614G in our study specimens provided valuable insight into the pace of epidemiological trend and the evolution of the virus early in the COVID-19 era through the New England region.

\section{Comparison With Prior Studies}

Many COVID-19 studies have found age to be a predictor of worse outcomes [3,37-40]. In our study, age was a significant predictor for all of the studied outcomes and was a confounder for other variables. Accordingly, LTC status predicted all three of our outcomes on univariate analysis but not on multivariate analyses, possibly because LTC units tend to have older residents. Earlier in the COVID-19 pandemic, residents of nursing homes had higher rates of infection and severe illness and mortality [41]. Our study shows disease outcomes were not impacted by their residence status after adjusting for age.

Concurrent work from our group suggests that $\mathrm{O}_{2}$ requirement within 24 hours of admission predicts poor outcomes in veterans, which has helped inform the triage guidelines at our health care system. This is an important finding because other ways of determining oxygenation status can frequently change and thus become difficult for clinicians to use in practice [22].

Our study supports data from previous reports that non-White patients in the United States are at increased risk of hospitalization but have similar peak severity and mortality outcomes [42,43]. Many studies have shown that minorities often have delays in seeking care, causing higher risk of hospitalization when they do seek care [44,45]. This may explain the outcomes in our study. It is critical to continue ongoing efforts to combat medical inequities and target prevention efforts and education to communities and racial groups most affected by COVID- 19 .

After adjusting for age and other comorbidities, we found that patients with dementia had a higher risk of death. This is similar to other studies on patients with COVID-19 and dementia $[37,46,47]$. This may be explained by a host of biological factors but also may be a result of the inability to self-report symptoms. This finding emphasizes the importance of extra care and monitoring required when approaching a patient with dementia.

\section{Limitations}

Limitations of this study include the smaller sample size. Furthermore, our study is specific to veterans, which is a largely male and older cohort, and results may not therefore be generalizable. The time period of this study was prior to established medical therapies for COVID-19, and our reported outcomes are likely worse than expected today. Strengths of 
our study include its comprehensive scope, wide geographic range, manual chart review process allowing for the capturing of all comorbidities and oxygenation parameters that may not be available otherwise in a database, and multivariate analysis of many potential risk factors.

\section{Conclusion}

Our study found that in an older cohort of veterans from the six New England states with a high comorbidity burden, age was the single strongest predictor of hospitalization, peak severity, and mortality. Non-White veterans were more likely to be hospitalized, and patients who required oxygen on admission were more likely to have severe disease and higher rates of mortality. Furthermore, patients with dementia were more likely to die. Multiple genomic variants of SARS-CoV-2 were distributed in patients in New England early in the COVID-19 era, mostly from a B.1 sublineage with the spike D614G mutation.

\section{Acknowledgments}

This study was supported by the Centers for Disease Control and Prevention (BAA 75D301-20-R-68024 to NDG and SG) and the Yale Center for Clinical Investigation TL1 TR001864 (MP).

\section{Authors' Contributions}

The authors confirm contribution to the manuscript as follows. ML and SG participated in the conception, design, data collection, analysis and interpretation of results, and manuscript preparation. YHS and MR participated in the data collection, analysis and interpretation of results, and manuscript preparation. MP and NDG participated in the conduction, analysis and interpretation of whole genome sequencing, and manuscript preparation. DC participated in the data collection and analysis and interpretation of results. CBFV, JRF, and TRA participated in the conduction and analysis of whole genome sequencing.

\section{Conflicts of Interest}

NDG is a paid consultant of Tempus Labs for infectious disease genomics.

\section{Multimedia Appendix 1}

Lineages of genomes.

[DOCX File, 14 KB-Multimedia Appendix 1]

\section{References}

1. Simonnet A, Chetboun M, Poissy J, Raverdy V, Noulette J, Duhamel A, LICORNthe Lille COVID-19 and Obesity study group. High prevalence of obesity in severe acute respiratory syndrome coronavirus-2 (SARS-CoV-2) requiring invasive mechanical ventilation. Obesity (Silver Spring) 2020 Jul;28(7):1195-1199 [FREE Full text] [doi: 10.1002/oby.22831] [Medline: 32271993]

2. Garg S, Kim L, Whitaker M, O'Halloran A, Cummings C, Holstein R, et al. Hospitalization rates and characteristics of patients hospitalized with laboratory-confirmed coronavirus disease 2019 - COVID-NET, 14 states, March 1-30, 2020. MMWR Morb Mortal Wkly Rep 2020 Apr 17;69(15):458-464. [doi: 10.15585/mmwr.mm6915e3] [Medline: 32298251]

3. Ioannou GN, Locke E, Green P, Berry K, O'Hare AM, Shah JA, et al. Risk factors for hospitalization, mechanical ventilation, or death among 10131 US veterans with SARS-CoV-2 infection. JAMA Netw Open 2020 Sep 01;3(9):e2022310 [FREE Full text] [doi: 10.1001/jamanetworkopen.2020.22310] [Medline: 32965502]

4. Richardson S, Hirsch JS, Narasimhan M, Crawford JM, McGinn T, Davidson KW, the Northwell COVID-19 Research Consortium, et al. Presenting characteristics, comorbidities, and outcomes among 5700 patients hospitalized with COVID-19 in the New York City Area. JAMA 2020 May 26;323(20):2052-2059 [FREE Full text] [doi: 10.1001/jama.2020.6775] [Medline: 32320003]

5. Wu C, Chen X, Cai Y, Xia J, Zhou X, Xu S, et al. Risk factors associated with acute respiratory distress syndrome and death in patients with coronavirus disease 2019 pneumonia in Wuhan, China. JAMA Intern Med 2020 Jul 01;180(7):934-943 [FREE Full text] [doi: 10.1001/jamainternmed.2020.0994] [Medline: 32167524]

6. People with certain medical conditions. Centers for Disease Control and Prevention. 2021. URL: https://www.cdc.gov/ coronavirus/2019-ncov/need-extra-precautions/people-with-medical-conditions.html [accessed 2021-09-13]

7. Pellicori P, Doolub G, Wong C, Lee K, Mangion K, Ahmad M, et al. COVID-19 and its cardiovascular effects: a systematic review of prevalence studies. Cochrane Database Syst Rev 2021 Mar 11;3:CD013879. [doi: 10.1002/14651858.CD013879] [Medline: $\underline{33704775]}$

8. Gao Y, Ding M, Dong X, Zhang J, Kursat Azkur A, Azkur D, et al. Risk factors for severe and critically ill COVID-19 patients: a review. Allergy $2021 \mathrm{Feb}$;6(2):428-455. [doi: 10.1111/all.14657] [Medline: 33185910 ]

9. Al-Salameh A, Lanoix J, Bennis Y, Andrejak C, Brochot E, Deschasse G, et al. Characteristics and outcomes of COVID-19 in hospitalized patients with and without diabetes. Diabetes Metab Res Rev 2021 Mar;37(3):e3388 [FREE Full text] [doi: 10.1002/dmrr.3388] [Medline: 32683744] 
10. Mason KE, Maudsley G, McHale P, Pennington A, Day J, Barr B. Age-adjusted associations between comorbidity and outcomes of COVID-19: a review of the evidence from the early stages of the pandemic. Front Public Health 2021;9:584182. [doi: 10.3389/fpubh.2021.584182] [Medline: 34422736]

11. Smati S, Tramunt B, Wargny M, Caussy C, Gaborit B, Vatier C, CORONADO investigators. Relationship between obesity and severe COVID-19 outcomes in patients with type 2 diabetes: results from the CORONADO study. Diabetes Obes Metab 2021 Feb;23(2):391-403 [FREE Full text] [doi: 10.1111/dom.14228] [Medline: 33051976]

12. Bello-Chavolla OY, Bahena-López JP, Antonio-Villa NE, Vargas-Vázquez A, González-Díaz A, Márquez-Salinas A, et al. Predicting mortality due to SARS-CoV-2: a mechanistic score relating obesity and diabetes to COVID-19 outcomes in Mexico. J Clin Endocrinol Metab 2020 Aug 01;105(8):dgaa346 [FREE Full text] [doi: 10.1210/clinem/dgaa346] [Medline: 32474598]

13. Li J, Huang DQ, Zou B, Yang H, Hui WZ, Rui F, et al. Epidemiology of COVID-19: a systematic review and meta-analysis of clinical characteristics, risk factors, and outcomes. J Med Virol 2021 Mar;93(3):1449-1458 [FREE Full text] [doi: 10.1002/jmv.26424] [Medline: 32790106]

14. Ko JY, Danielson ML, Town M, Derado G, Greenlund KJ, Kirley PD, COVID-NET Surveillance Team. Risk factors for coronavirus disease 2019 (COVID-19)-associated hospitalization: COVID-19-associated hospitalization surveillance network and behavioral risk factor surveillance system. Clin Infect Dis 2021 Jun 01;72(11):e695-e703 [FREE Full text] [doi: 10.1093/cid/ciaa1419] [Medline: $\underline{32945846]}$

15. Breland JY, Wong MS, Steers WN, Yuan AH, Haderlein TP, Washington DL. BMI and risk for severe COVID-19 among veterans health administration patients. Obesity (Silver Spring) 2021 May;29(5):825-828. [doi: 10.1002/oby.23121] [Medline: 33403755]

16. SARS-CoV-2 variant classifications and definitions. Centers for Disease Control and Prevention. URL: https://www.cdc.gov/ coronavirus/2019-ncov/variants/variant-info.html [accessed 2021-09-13]

17. Korber B, Fischer WM, Gnanakaran S, Yoon H, Theiler J, Abfalterer W, Sheffield COVID-19 Genomics Group, et al. Tracking changes in SARS-CoV-2 spike: evidence that D614G increases infectivity of the COVID-19 virus. Cell 2020 Aug 20;182(4):812-827.e19 [FREE Full text] [doi: 10.1016/j.cell.2020.06.043] [Medline: 32697968]

18. Tracking SARS-CoV-2 variants. World Health Organization. URL: https://www.who.int/en/activities/ tracking-SARS-CoV-2-variants/ [accessed 2021-09-13]

19. Rambaut A, Holmes EC, O'Toole Á, Hill V, McCrone JT, Ruis C, et al. A dynamic nomenclature proposal for SARS-CoV-2 lineages to assist genomic epidemiology. Nat Microbiol 2020 Nov;5(11):1403-1407 [FREE Full text] [doi:

10.1038/s41564-020-0770-5] [Medline: $\underline{\text { 32669681] }}$

20. Daniloski Z, Jordan TX, Ilmain JK, Guo X, Bhabha G, tenOever BR, et al. The Spike D614G mutation increases SARS-CoV-2 infection of multiple human cell types. Elife 2021 Feb 11;10:e65365. [doi: 10.7554/eLife.65365] [Medline: 33570490]

21. Census Bureau releases 2020 demographic analysis estimates. United States Census Bureau. URL: $\underline{\text { https://www.census.gov/ }}$ newsroom/press-releases/2020/2020-demographic-analysis-estimates.html [accessed 2021-09-13]

22. Profile of veterans: 2017. US Department of Veterans Affairs. 2017. URL: https://www.va.gov/vetdata/docs/SpecialReports/ Profile of Veterans 2017.pdf [accessed 2021-09-13]

23. Jin J, Bai P, He W, Wu F, Liu X, Han D, et al. Gender differences in patients with COVID-19: focus on severity and mortality. Front Public Health 2020;8:152. [doi: 10.3389/fpubh.2020.00152] [Medline: 32411652]

24. Gallo Marin B, Aghagoli G, Lavine K, Yang L, Siff EJ, Chiang SS, et al. Predictors of COVID-19 severity: a literature review. Rev Med Virol 2021 Jan;31(1):1-10 [FREE Full text] [doi: 10.1002/rmv.2146] [Medline: 32845042]

25. Liu D, Wang Y, Wang J, Liu J, Yue Y, Liu W, et al. Characteristics and outcomes of a sample of patients with COVID-19 identified through social media in Wuhan, China: observational study. J Med Internet Res 2020 Aug 13;22(8):e20108 [FREE Full text] [doi: 10.2196/20108] [Medline: 32716901]

26. Peckham H, de Gruijter NM, Raine C, Radziszewska A, Ciurtin C, Wedderburn LR, et al. Male sex identified by global COVID-19 meta-analysis as a risk factor for death and ITU admission. Nat Commun 2020 Dec 09;11(1):6317. [doi: 10.1038/s41467-020-19741-6] [Medline: 33298944]

27. Harada K, McConnell I, DeRycke EC, Holleck JL, Gupta S. Native joint septic arthritis: comparison of outcomes with medical and surgical management. South Med J 2019 Apr;112(4):238-243. [doi: 10.14423/SMJ.0000000000000958] [Medline: 30943544]

28. Clinical Laboratory Improvement Amendments (CLIA). Centers for Medicare and Medicaid Services. 2021. URL: $\underline{\text { https:/ }}$ /www.cms.gov/Regulations-and-Guidance/Legislation/CLIA [accessed 2021-09-13]

29. Katoh K, Standley DM. MAFFT multiple sequence alignment software version 7: improvements in performance and usability. Mol Biol Evol 2013 Apr;30(4):772-780 [FREE Full text] [doi: 10.1093/molbev/mst010] [Medline: 23329690]

30. De Maio N, Walker C, Borges R, Weilguny L, Slodkowicz G, Goldman N. Masking strategies for SARS-CoV-2 alignments. Virological. 2020. URL: https://virological.org/t/masking-strategies-for-sars-cov-2-alignments/480 [accessed 2021-09-13]

31. Minh B, Schmidt H, Chernomor O, Schrempf D, Woodhams M, von Haeseler A, et al. IQ-TREE 2: new models and efficient methods for phylogenetic inference in the genomic era. Mol Biol Evol 2020 May 01;37(5):1530-1534 [FREE Full text] [doi: 10.1093/molbev/msaa015] [Medline: 32011700] 
32. Shang W, Dong J, Ren Y, Tian M, Li W, Hu J, et al. The value of clinical parameters in predicting the severity of COVID-19. J Med Virol 2020 Oct;92(10):2188-2192 [FREE Full text] [doi: 10.1002/jmv.26031] [Medline: $\underline{32436996]}$

33. Merzon E, Green I, Shpigelman M, Vinker S, Raz I, Golan-Cohen A, et al. Haemoglobin A1c is a predictor of COVID-19 severity in patients with diabetes. Diabetes Metab Res Rev 2021 Jul;37(5):e3398 [FREE Full text] [doi: 10.1002/dmrr.3398] [Medline: $\underline{\text { 32852883] }}$

34. Zhou F, Yu T, Du R, Fan G, Liu Y, Liu Z, et al. Clinical course and risk factors for mortality of adult inpatients with COVID-19 in Wuhan, China: a retrospective cohort study. Lancet 2020 Mar 28;395(10229):1054-1062 [FREE Full text] [doi: 10.1016/S0140-6736(20)30566-3] [Medline: $\underline{\text { 32171076] }}$

35. Benchimol EI, Smeeth L, Guttmann A, Harron K, Moher D, Petersen I, RECORD Working Committee. The Reporting of Studies Conducted Using Observational Routinely-Collected Health Data (RECORD) statement. PLoS Med 2015 Oct;12(10):e1001885 [FREE Full text] [doi: 10.1371/journal.pmed.1001885] [Medline: 26440803]

36. Ajufo E, Rao S, Navar AM, Pandey A, Ayers CR, Khera A. U.S. population at increased risk of severe illness from COVID-19. Am J Prev Cardiol 2021 Jun;6:100156 [FREE Full text] [doi: 10.1016/j.ajpc.2021.100156] [Medline: 33615285]

37. Docherty AB, Harrison EM, Green CA, Hardwick HE, Pius R, Norman L, ISARIC4C investigators. Features of 20133 UK patients in hospital with covid-19 using the ISARIC WHO Clinical Characterisation Protocol: prospective observational cohort study. BMJ 2020 May 22;369:m1985 [FREE Full text] [doi: 10.1136/bmj.m1985] [Medline: 32444460]

38. Giorgi Rossi P, Marino M, Formisano D, Venturelli F, Vicentini M, Grilli R, Reggio Emilia COVID-19 Working Group. Characteristics and outcomes of a cohort of COVID-19 patients in the Province of Reggio Emilia, Italy. PLoS One 2020;15(8):e0238281 [FREE Full text] [doi: 10.1371/journal.pone.0238281] [Medline: $\underline{32853230]}$

39. Kim L, Garg S, O'Halloran A, Whitaker M, Pham H, Anderson EJ, et al. Risk factors for intensive care unit admission and in-hospital mortality among hospitalized adults identified through the US Coronavirus Disease 2019 (COVID-19)-Associated Hospitalization Surveillance Network (COVID-NET). Clin Infect Dis 2021 May 04;72(9):e206-e214 [FREE Full text] [doi: 10.1093/cid/ciaa1012] [Medline: 32674114]

40. Williamson EJ, Walker AJ, Bhaskaran K, Bacon S, Bates C, Morton CE, et al. Factors associated with COVID-19-related death using OpenSAFELY. Nature 2020 Aug;584(7821):430-436 [FREE Full text] [doi: 10.1038/s41586-020-2521-4] [Medline: $\underline{\text { 32640463] }}$

41. Bagchi S, Mak J, Li Q, Sheriff E, Mungai E, Anttila A, et al. Rates of COVID-19 among residents and staff members in nursing homes - United States, May 25-November 22, 2020. MMWR Morb Mortal Wkly Rep 2021 Jan 15;70(2):52-55. [doi: 10.15585/mmwr.mm7002e2] [Medline: 33444301]

42. Cardemil CV, Dahl R, Prill MM, Cates J, Brown S, Perea A, et al. COVID-19-related hospitalization rates and severe outcomes among veterans from 5 Veterans Affairs medical centers: hospital-based surveillance study. JMIR Public Health Surveill 2021 Jan 22;7(1):e24502 [FREE Full text] [doi: 10.2196/24502] [Medline: $\underline{33338028]}$

43. Gold JAW, Wong KK, Szablewski CM, Patel PR, Rossow J, da Silva J, et al. Characteristics and clinical outcomes of adult patients hospitalized with COVID-19 - Georgia, March 2020. MMWR Morb Mortal Wkly Rep 2020 May 08;69(18):545-550. [doi: 10.15585/mmwr.mm6918e1] [Medline: 32379729]

44. Hall WJ, Chapman MV, Lee KM, Merino YM, Thomas TW, Payne BK, et al. Implicit racial/ethnic bias among health care professionals and its influence on health care outcomes: a systematic review. Am J Public Health 2015 Dec;105(12):e60-e76. [doi: 10.2105/ajph.2015.302903]

45. Nelson A. Unequal treatment: confronting racial and ethnic disparities in health care. J Natl Med Assoc 2002 Aug;94(8):666-668. [Medline: 12152921]

46. Harrison SL, Fazio-Eynullayeva E, Lane DA, Underhill P, Lip GYH. Comorbidities associated with mortality in 31,461 adults with COVID-19 in the United States: a federated electronic medical record analysis. PLoS Med 2020 Sep;17(9):e1003321 [FREE Full text] [doi: 10.1371/journal.pmed.1003321] [Medline: 32911500 ]

47. Miyashita S, Yamada T, Mikami T, Miyashita H, Chopra N, Rizk D. Impact of dementia on clinical outcomes in elderly patients with coronavirus 2019 (COVID-19): an experience in New York. Geriatr Gerontol Int 2020 Jul;20(7):732-734 [FREE Full text] [doi: 10.1111/ggi.13942] [Medline: $\underline{32691924]}$

\section{Abbreviations}

CAD: coronary artery disease

CDC: Centers for Disease Control and Prevention

Ct: cycle threshold

LTC: long-term care

NC: nasal cannula

OR: odds ratio

REPORT: Reporting of Studies Conducted Using Observational Routinely-Collected Data

VA: Veterans Affairs

VACHS: VA Connecticut Healthcare System

WGS: whole genome sequencing 
Edited by E Meinert; submitted 25.06.21; peer-reviewed by M Mbwogge, L Guo; comments to author 07.09.21; revised version received 14.09.21; accepted 04.11.21; published 17.12.21

Please cite as:

Lee M, Sallah YH, Petrone M, Ringer M, Cosentino D, Vogels CBF, Fauver JR, Alpert TD, Grubaugh ND, Gupta S

COVID-19 Outcomes and Genomic Characterization of SARS-CoV-2 Isolated From Veterans in New England States: Retrospective Analysis

JMIRx Med 2021;2(4):e31503

URL: https://med.jmirx.org/2021/4/e31503

doi: $10.2196 / 31503$

PMID: $\underline{35014989}$

CMegan Lee, Ya Haddy Sallah, Mary Petrone, Matthew Ringer, Danielle Cosentino, Chantal B F Vogels, Joseph R Fauver, Tara D Alpert, Nathan D Grubaugh, Shaili Gupta. Originally published in JMIRx Med (https://med.jmirx.org), 17.12.2021. This is an open-access article distributed under the terms of the Creative Commons Attribution License (https://creativecommons.org/licenses/by/4.0/), which permits unrestricted use, distribution, and reproduction in any medium, provided the original work, first published in JMIRx Med, is properly cited. The complete bibliographic information, a link to the original publication on https://med.jmirx.org/, as well as this copyright and license information must be included. 